\title{
The Influence of Cooperative Learning Through Authentic Assessment-Based Jigsaw on Social Development of Early Childhood
}

\section{Wayan Karta ${ }^{1 *}$, Ika Rachmayani ${ }^{2}$, Ni Wayan Rasmini ${ }^{3}$}

1,2 Mataram University, Department of Early Childhood Education, Mataram University, Mataram, Indonesia

${ }^{3}$ Faculty of Education. Gde Pudja Hindu Institute, Mataram, Indonesia

*e-mail: kartaiwayan5@gmail.com

\begin{abstract}
The early childhood education system nowadays requires the use of authentic assessment in schools. Authentic assessment is an integrative method of assessing the learning process, reflective to the real-world situations, using varieties methods and holistic criteria to assess the cognitive, affective, and skills in early childhood. Social development occurs dominantly after physical, cognitive, and language developments. Based on the minimal developmental standard, many early-childhood children show substandard development in environment adaptation ability, self-managing ability, responsibility, ability to follow rules, sharing, respecting others, cooperation, toleration, and emotional expression. This study aims to identify the influence of cooperative learning through authentic assessment-based jigsaw in the social development of early childhood. This study uses a pre-test post-test design on 50 subjects aged 5-6 years old. The experiment was carried out in 4 stage with 4 learning sub-themes. Data collected with a 1-4 scale observation instrument to get quantitative data and analyzed using t-Test. Results from data analysis concluded that cooperative learning through authentic assessment-based jigsaw has a positive influence on social development in early childhood. We recommend the implementation of this method to optimize social development in early childhood.
\end{abstract}

Keywords: Cooperative Learning Jigsaw, Authentic Assessment, Social Development

\section{Introduction}

Education and learning are forms of social interaction between adults and growing people, following learning resources, aiming to create responsible adults (Kolhar et al., 2021; Nugraha et al., 2016). The cooperative learning method could be used to achieve the learning objective aimed to develop the human ability to interact with other people (Diartini \& Ratnawuri, 2017; Nurhusain, 2017). Cooperative learning refers to various kinds of learning models where students work together in small groups consist of various levels of achievement, different genders, and multiethnic backgrounds to mutually help one another in learning (Haryanti, 2016; Hengki et al., 2017). Cooperative learning has a positive effect on the academic achievement of socio-psychology lessons. Cooperative learning has a positive effect on students' performance and attitude (Hossain \& Tarmizi, 2013; Qusyairi \& Sakila, 2018). Learning by jigsaw significantly increases learners' responsibility (Nashirotun, 2020; M. K. Sari, 2014; Zakiah \& Samlawi, 2019). Cooperative and student-centered learning create higher learning outcomes and students believe that jigsaw effectively evokes interpersonal attitudes, interests, and skills (Marhamah \& Mulyadi, 2013; Nurhusain, 2017; Yuan \& Wu, 2020). Jigsaw strategies are more effective than traditional teaching in increasing academic achievement and students' positive attitudes (Subiyantari et al., 2019; Yemi et al., 2018). There have been found theories, procedures, and roles of teachers in implementing the cooperative learning method, both formal and informal. They have been theoretically validated, modified, improved, and expanded. Cooperative learning process using jigsaw yields higher cognitive study outcomes and a higher number of critical students (Marhamah \& Mulyadi, 2013; Subiyantari et al., 2019).

\section{${ }^{*}$ Corresponding author.}

Received May 07, 2021; Accepted June 01, 2021; Available online December 25, 2021

This is an open access article under the CC BY-SA license. Copyright $(2021$ by Author. Published by Universitas Pendidikan Ganesha 
Students in the cooperative group discover more learning benefits compared to those in the traditional learning group. Student-centered cooperative learning creates relatively equal results when applied to different learning styles (Çolak, 2015; Hertiavi et al., 2010). Jigsaw learning is a type of cooperative learning method that encourages active participation and mutual help among students throughout the learning process to achieve the maximum result (Hengki et al., 2017; Souvignier \& Kronenberger, 2007; Zakiah \& Samlawi, 2019). The jigsaw method can also improve problem-solving skills and has a positive impact on the achievement of health and sport physiology (Hertiavi et al., 2010; Sean Kelly, Andrew M. Olney, 2013). Jigsaw could increase the responsibility of the students in social sciences (Yemi et al., 2018; Zakiah \& Samlawi, 2019). Jigsaw is found to be effective in terms of students' self-confidence (Hijrihani \& Wutsqa, 2015). Cooperative learning improves elaborative thought and has the potential to improve understanding, reasoning, and resistance over a long period (Devi et al., 2016; Nashirotun, 2020).

Jigsaw cooperative learning is an active learning method using heterogeneous study groups (usually 4-5 students) in the learning process (Hijrihani \& Wutsqa, 2015; Saguni, 2013). Every group member shares responsibility to master parts of the learning material and to tutor fellow group members. Jigsaw cooperative learning stimulates students to actively interact intra-group and inter-groups (Subiyantari et al., 2019; Widyaningrum \& Harjono, 2019). This interaction could be used in developing social competency in children. Assessment is a double-edged dagger with double meanings, living side by side to better improve the policy assessment through the integration of technology and the teachers' development of assessment competency (Sinclair, 2017; Supriyadi et al., 2019). Authentic assessment is a systematic method to gather information about the achievement and development of children through natural observation. This approach can be applied in scientific experiments, social research, report writing, reading and interpreting literature, and completing applicative questions. Teachers may use assessment to promote the independence of the students in a game-based class (Christopher DeLuca, Angela Pyle, n.d.; Usmanova et al., 2015). The design of education and assessment influenced by the theory of pedagogy, teaching, and learning, and discipline of the students along with the wider context of education (Wiliam, 2018). There is a strong positive correlation between the view of formative assessment and that of assessment as a promotion of student accountability (Johnston, 2017).

Instead of multi-technic assessment methods, the conventional early childhood learning process usually implements the use of summative assessment at the middle and the end of the semester. This results in the inability to comprehensively and authentically assessing the learning results. The authentic assessment method is valid and proper to be used to increase the learning competencies (Efendi \& Irawati, 2021; Faizah et al., 2019). Implementation of qualified authentic assessment requires improvement in terms of preparation and availability of assessment tools, as well as increasing teacher competency in the field of assessment (Kartowagiran \& Jaedun, 2016; Ozan, 2019). Students' self-appraisal and their ability to integrate cognitive, motivation, and attitude could increase with their engagement in learning. The application of authentic assessment is very meaningful in the Biology learning process (Lynch et al., 2021; Pantiwati, 2016). The application of ongoing guidance can improve the ability of teachers to carry out authentic assessments. An authentic assessment is conducted in integrative collaboration with the learning process to motivate the students to learn credibly.

Social development is the attainment of maturity in social relationships (Majid et al., 2012; Susanto, 2012). The aspect of social competence in early age children consists of the ability to mingle, socialize, communicate, cooperate, patience, care, help, tolerance, and responsibility (Bekhet \& Garnier-Villarreal, 2018; Musyarofah, 2018). Social-emotional development should be endeavored at preschool age, at home, or out of the house with peers from various intercultural backgrounds. Differences have been found in the social development of children aged 3-6 years between the Early Childhood Education group and that without Early Childhood Education (Musyarofah, 2018; Wulandari et al., 2017). A study to map the social development in early childhood conducted by Tatminingsih found that on 
average, the children still required intensive tutoring and example from the teacher to develop their social skills (Tatminingsih, 2019). For the children to develop the expected social behaviors, both parents and teachers must play active roles and pay attention to the needs and development of the children.

Cooperative learning affects the development of social behavior (Mulyana et al., 2016; Nurmahmidah, 2017). Interaction during plays is a social tool used by children to support and maintain their interactions. The implementation of the jigsaw cooperative learning method could increase the skills in the learning process and learning results $(\mathrm{M}$. K. Sari, 2014; Soedimardjono \& Pratiwi, 2021). Prior studies indicated that the jigsaw cooperative learning with priority on the interaction among groups of children is potential to the development of the social competencies of the children (Nashirotun, 2020; Nurmiyati \& Suyata, 2014; Wardani, 2015). Cooperative learning through the authentic assessmentbased jigsaw method can stimulate and facilitate the intra-group and inter-group interaction between the early childhood students to reach optimal learning results. This method is seldom implemented due to the requirements for the teachers to have the ability in managing group activities as the learning focus. Limited ability to express oneself and language differences in children are also the reason this method is seldom implemented. The implementation of the authentic assessment-based jigsaw cooperative learning method could be a continuing solution to the problem of substandard social development in early childhood. This study aims to analyze the level of influence of the application of Jigsaw cooperative learning on the social development of early childhood students.

\section{Method}

This research is quantitative comparative experimental research. Subjects for this study were 50 class B students from 3 preschools in Mataram, West Nusa Tenggara. Schools were chosen using stratified cluster sampling based on school accreditation standards $A, B$, and $C$. In each stratum, one kindergarten chose using the lottery technique. Schools chosen were Pembina Public Preschool, Aisyiyah Bustanul Athfal 5 Islamic Preschool, and Cendekia Islamic Preschool. The experiment was carried out in four stages based on the "Myself" learning theme and 4 sub-themes: My identity, My body, Five Senses, and My passions. Learning processes are carried out in 20 effective working days, with 5 days for every sub-theme. Each learning activity ran based on the lesson plan made beforehand. Experiments carried out by class B teachers. The data collection employed the guidelines instrument for observation, conducted by the observer to observe the cooperative jigsaw learning based on authentic assessment and the resulted social development of the children. Data collection instruments had been tested for content and item validity and reliability before the experiment. The content validity test was conducted by two experts (of measurements and content) and analyzed using the Gregory formula. Empirical validity (item validity) tested using the product-moment technique. The reliability analysis of the instrument tested using the Kolmogorov Smirnov technique. The instrument for social development was in the form of a 1 to 4 rating scale.

Pre-test data on the students' social development obtained from the final semester report before the implementation of the jigsaw method. Jigsaw method implemented in every learning theme for 5 effective school days with one daily learning plan used every day. Data collected using the observation guideline instruments on authentic assessment applied in the learning process. At the end of every subtheme, data recapitulation on the social development of the students were collected, thus there are four social development data for every subtheme. The data on social development then collectively obtained from the score of the fourth experiment $(\mathrm{Y})$, which was then used as the post-test data. The instrument used in social development data collection is an observation guideline consists of 16 Linkert-scale items in four categories $(4,3,2,1)$. The instrument is arranged based on the indicator of developmental achievement in children aged 5-6 years old. The data obtained were interval data with a minimum score of 16 and a maximum score of 64 . Observational data on social development for each subtheme and post-test social development then transformed to 
percentage standard to equalize it. The data then analyzed using a descriptive statistic to obtain the mean, median, and modus. It is then used to describe the students' social developmental achievement. The hypothesis then tested using a t-test to find the difference in mean between pre-test and post-test using a 0.05 (5\%) significance level.

\section{Result and Discussion}

\section{Results}

Experimental research conducted 4 times using pre-test and post-test design. In every experiment, the observer measures the quality of learning and social development. The first treatment covered the sub-theme of My Body, the second covered the sub-theme of the Five Senses, the third sub-theme of My Favorites, and the four the sub-theme of My Identity. The social development data consists of pre-test (X1), the first treatment (X2), the second treatment $(\mathrm{X} 3)$, the third treatment $(\mathrm{X} 4)$, and the fourth treatment $(\mathrm{Y})$. The instrument of social development on children at an early age contains several sub-aspects, namely: communicating with friends when doing activities, understanding, and following rules, acting cooperatively with friends, caring with friends, and being enthusiastic when doing activities. Meanwhile, the instrument of implementation of the jigsaw cooperative learning contains some aspects, namely: creating a design study, explaining the theme and sub-theme, explaining the process of the implementation of learning, providing motivation, conducting evaluations with authentic assessment, and giving awards. The measurement of the social development, four experiments of four sub-themes, shows that the most prominent results found in the third experiment when discussing the sub-theme of "My Favorites". The calculation used is the average score standard. The descriptive analysis shows that based on the provision of jigsaw-type cooperative learning, early childhood social development increases by $5 \%$ from $65 \%$ in the pre-test to $70 \%$ in the post-test.

Table 1. Result of T-Test Data Analysis on Social Development of Early Childhood: Pre-Test \& Post-Test

\begin{tabular}{|c|c|c|c|c|c|c|}
\hline \multirow{2}{*}{ Variable } & \multirow[t]{2}{*}{$\mathbf{t}$} & \multirow[t]{2}{*}{ df } & \multirow{2}{*}{$\begin{array}{l}\text { Sig. (2- } \\
\text { tailed) }\end{array}$} & \multirow{2}{*}{$\begin{array}{c}\text { Mean } \\
\text { Difference }\end{array}$} & \multicolumn{2}{|c|}{$\begin{array}{c}95 \% \text { Confidence Interval } \\
\text { of the Difference }\end{array}$} \\
\hline & & & & & Lower & Upper \\
\hline $\mathrm{X} 1$ & 32.173 & 49 & 0.000 & 2.60000 & 2.4376 & 2.7624 \\
\hline $\mathrm{X} 2$ & 31.715 & 49 & 0.000 & 2.83500 & 2.6554 & 3.0146 \\
\hline X3 & 35.338 & 49 & 0.000 & 2.90000 & 2.7351 & 3.0649 \\
\hline $\mathrm{X} 4$ & 33.299 & 49 & 0.000 & 3.04000 & 2.8565 & 3.2235 \\
\hline Y & 45.715 & 49 & 0.000 & 2.84040 & 2.7155 & 2.9653 \\
\hline
\end{tabular}

Corresponding to the result above, it can be concluded that there exists a positive and significant influence of jigsaw authentic assessment-based cooperative learning on the social development of early-age children in Mataram.

\section{Discussion}

Jigsaw Cooperative Learning is a series of activities performed by the students in a specific group to achieve the expected learning goals (Edriati et al., 2015; M. K. Sari, 2014). Students learn and work in small collaborative groups whose members (4-6) are heterogeneous (Nurfitriyanti, 2017; Nurmiyati \& Suyata, 2014). This learning method is designed to encourage cooperation among students during the learning process. Jigsaw cooperative learning is a learning model that encourages students to be active and help each other in mastering the material to achieve maximum achievement (Wardani, 2015; Wardani \& Wiyasa, 2020). The teacher acts as a facilitator to directs and motivates students to learn independently and foster a sense of responsibility. Jigsaw learning is a learning which is designed specifically to encourage the students to collaborate in small groups with 
heterogeneous members (Anwar, 2018; Leniati \& Indarini, 2021). By prioritizing interactions between small groups of children with others, this technique can develop children's social competence. Children will learn to adjust to the norms of the group and merged themselves into a single entity to communicate and work together based on the norms of morality and tradition.

Authentic assessment, just like other kinds of assessments, is a systematic procedure that involves data collection, analysis, and information interpretation to make decisions about the characteristics of the object measured. Authentic assessment in the early childhood learning process is used to assess the planning, execution, and learning results (Hairida, 2016; Hartati \& Zulminiati, 2020). Assessment in the context of Early Childhood learning is an effort to collect, analyze and interpret various information about the performance and progress of various aspects of development that can be achieved by children after participating in habituation activities in a certain period. An authentic assessment refers to real-world situations with several approaches to solve various problems. Authentic assessment-based jigsaw cooperative learning method significantly influences the social development of children. The learning process prioritizes activities such as mutual argumentation, discussion, and mutual assistance to hone their knowledge in filling each other's gaps. Learning like this enables social interactions to take place openly interdependently. An authentic assessment is a fact-based assessment of behavior as an indication of learning activities from beginning to end to figure out children's growth and development (Nurfitriyanti, 2017; Wardani, 2015).

Jigsaw cooperative and motivational learning impact positively on the achievement of learning (Sean Kelly, Andrew M. Olney, 2013; Wardani \& Wiyasa, 2020). There are differences between the social development of children aged 3-6 years participating in preschool and that of those who do not (Wulandari et al., 2017). The authentic assessment instrument is valid and has practical and effective use to record student skills. The product of authentic assessment in learning education civics is found to be very valid and has adequate applicability and readability. Teachers have applied authentic assessment methods in the learning process to assess cognitive, affective, and psycho-motoric aspects proportionally. Both lecturers and students suggest that the authentic assessment is a good and precise option to assess the qualified results of studying.

The social development of the early-age children in jigsaw learning also follows the theory of Bandura's (model learning), especially in the aspect of imitating and observing others (Khadijah et al., 2021; Sari et al., 2019). Learning through collaborative games that encourage children's interaction could increase social skills in early childhood (Ananda \& Fadhilaturrahmi, 2018; Astarini et al., 2017). to apply observational learning. In observational learning, things learned by individuals for simple social behaviors, learners use the concept of imitation. However, for complex social development, to avoid undesired outcomes on the imitated or copied actions, the learners need are first processed cognitively, and then learners will act according to the information produced. Information obtained from observation will be processed only if the individual deemed it important to do so. In the implementation of the concept of imitation and observational learning in the jigsaw technique, the development of the learning scenario is conducted in a way that students feel in need of the process and outcomes of learning so that they become motivated to apply the results of the learning in real-life situations. Learning interactions during the Jigsaw technique application shown important symbols derived from model learning of both teachers and classmates.

Researchers found that the jigsaw cooperative method has not been implemented collaboratively with the authentic assessment. The result of this study found that the application of authentic assessment-based jigsaw learning method in the learning process created a holistic social development in cognitive, affective, psychomotor, and behavior fields. Authentic assessment hasn't been optimally applied by preschool teachers in comprehensive assessments. The application of the authentic assessment-based jigsaw method focused on group discussions facilitates the conceptual understanding and learning material analysis in early childhood students (Hasibuan et al., 2020; Putra et al., 2018). The 
jigsaw cooperative learning model improved the learning results from low level to higher level in social study learning subject (Edriati et al., 2015; Widyaningrum \& Harjono, 2019).

The collaborative authentic assessment-based jigsaw method is repeatedly implemented 12 times using 3 different learning themes. The repetitive learning process could facilitate the development of critical thinking habits and the formation of meta-cognitive competency. The meta-cognitive competency in children is the result of holistic (knowledgeattitude-skill-behavior) learning through interactions between individuals within groups. The jigsaw learning with the thematic approach aimed to achieve comprehensive social development, from the process of learning and achievement outcomes of learning (Edriati et al., 2015; M. K. Sari, 2014). The process of learning by an individual within the group happened in the process of examining a theme to reach optimum competence. The behaviorist theory prioritizes partial behavioral change in developing maturity does not support the results of this research. Learning outcomes that observable to an environmental standard tend to be elementary, molecular, objective, empirical, and behavioristic. Learning outcomes are expressed as the sum of the elements that appear in behavior.

Implementation of the results contributes positively to solve the problem of low learning outcomes in terms of students' social development. It is deemed important to improve teacher competence in managing the learning process, developing the students' ability to communicate within a group and ability to understand and follow rules of games, being cooperative, caring for friends, and enthusiastic about doing activities (Anwar, 2018; Nurfitriyanti, 2017; Wardani, 2015). It is expected from the early childhood education institutions to be able to educate and motivate the children to become socially mature individuals. This study faces some limitations, ex: the area studied was limited to one city, the experiment conducted in only three schools, learning material limited to one learning theme, and the validity of the content of the instrument analyzed rationally. This study recommends teachers and managers of early childhood educational institutions apply the jigsaw technique to improve the social development in children. Learning steps are conducted consequently; adequate teaching aids are used; and assessment conducted authentically so that the children's development can be described as objective, transparent, and educative.

\section{Conclusions and Suggestions}

Authentic assessment-based jigsaw cooperative learning method is significantly and positively affecting the social development in early childhood students in Mataram, West Nusa Tenggara. Teachers and educational society might benefit from the inclusion of this method in the learning plans and the implementation in the everyday learning process. Implementation of this method in learning plans in collaboration with the observation of the learning process and students' behaviors will enable teachers to validly described the social development indicators in children.

\section{References}

Ananda, R., \& Fadhilaturrahmi, F. (2018). Peningkatan Kemampuan Sosial Emosional Melalui Permainan Kolaboratif pada Anak KB. Jurnal Obsesi : Jurnal Pendidikan Anak Usia Dini, 2(1), 20. https://doi.org/10.31004/obsesi.v2i1.3.

Anwar, M. (2018). Perbandingan Model Pembelajaran Kooperatif Tipe Jigsaw Dan Tipe Two Stay Two Stray Terhadap Kemampuan Berpikir Kritis Siswa Pada Materi Elastisitas. Jurnal Riset Fisika Edukasi Dan Sains, 5(2). https://doi.org/10.22202/jrfes.2018.v5i2.2750.

Astarini, N., Hamid, S. I., \& Rustini, T. (2017). Studi Dampak Tavangan Televisi Terhadap Perkembangan Perilaku Sosial Anak. Cakrawala Dini: Jurnal Pendidikan Anak Usia Dini, 8(1). https://doi.org/10.17509/cd.v8i1.10554.

Bekhet, A. K., \& Garnier-Villarreal, M. (2018). Depression, positive thinking, personal and social resourcefulness among caregivers of persons with autism spectrum disorders. 
Archives of Psychiatric Nursing, 36(2). https://doi.org/10.1016/j.apnu.2018.06.006.

Christopher DeLuca, Angela Pyle, H. B. \& L. F. (n.d.). Leveraging assessment to promote kindergarten learners' independence and self-regulation within play-based classrooms. https://doi.org/10.1080/0969594X.2020.1719033.

Çolak, E. (2015). The effect of cooperative learning on the learning approaches of students with different learning styles. Egitim Arastirmalari - Eurasian Journal of Educational Research, 59, 17-34. https://doi.org/10.14689/ejer.2015.59.2.

Devi, A. P., Musthafa, B., \& Gustine, G. G. G. (2016). Using Cooperative Learning In Teaching Critical Thinking In Reading. English Review: Journal of English Education, 4(1), 1. https://doi.org/10.25134/erjee.v4i1.310.

Diartini, R., \& Ratnawuri, T. (2017). Penggunaan Model Cooperative Learning Tipe Probing Prompting Berbantu Media Flash Card Terhadap Hasil Belajarips Terpadu. PROMOSI (Jurnal Pendidikan Ekonomi), 5(1), 57-63. https://doi.org/10.24127/ja.v5i1.846.

Edriati, S., Anggraini, V., \& Siska, M. (2015). Efektivitas Model Jigsaw Disertai Penilaian Diskusi Untuk Meningkatkan Kemampuan Matematis Mahasiswa. Cakrawala Pendidikan, 1(2). https://doi.org/10.21831/cp.v2i2.4833.

Efendi, R., \& Irawati, Y. (2021). Designing the E-Authentic Assessment on Computer Networking Learning in The Revolution Industry 4 . 0. 10(1), 190-201. https://doi.org/10.23887/jpi-undiksha.v10i1.24431.

Faizah, U., Zuchdi, D., \& Alsamiri, Y. (2019). An authentic assessment model to assess kindergarten students' character. Research and Evaluation in Education, 5(2), 103119. https://doi.org/10.21831/reid.v5i2.24588.

Hairida, H. (2016). The effectiveness using inquiry based natural science module with authentic assessment to improve the critical thinking and inquiry skills of junior high school students. Jurnal Pendidikan IPA Indonesia, 5(2), 209-215. https://doi.org/10.15294/jpii.v5i2.7681.

Hartati, S., \& Zulminiati, Z. (2020). Fakta-Fakta Penerapan Penilaian Otentik di Taman Kanak-Kanak Negeri 2 Padang. Jurnal Obsesi: Jurnal Pendidikan Anak Usia Dini, 5(2), 1035-1044. https://doi.org/10.31004/obsesi.v5i2.521.

Haryanti, Y. D. (2016). Peningkatan Hasil Belajar Dengan Menggunakan Model Cooperative Learning Type Inside-Outside Circle. Jurnal Cakrawala Pendas, 2(2). https://doi.org/10.31949/jcp.v2i2.337.

Hasibuan, M. H. E., Fuldiaratman, F., Dewi, F., Sulistiyo, U., \& Hindarti, S. (2020). Jigsaw Learning Strategy In A Diverse Science-Classroom Setting: Feasibility, Challenges, And Adjustment. Cakrawala Pendidikan, https://doi.org/10.21831/cp.v39i3.30634.

Hengki, H., Jabu, B., \& Salija, K. (2017). The Effectiveness of Cooperative Learning Strategy through English Village for Teaching Speaking Skill. Journal of Language Teaching and Research, 8(2), 306. https://doi.org/10.17507/jltr.0802.12.

Hertiavi, M. A., Langlang, H., \& Khanafiyah, S. (2010). Penerapan Model Pembelajaran Kooperatif Tipe Jigsaw Untuk Peningkatan Kemampuan Pemecahan Masalah Siswa Smp. Jurnal Pendidikan Fisika Indonesia, 6(1), 53-57. https://doi.org/10.15294/jpfi.v6i1.1104.

Hijrihani, C. P., \& Wutsqa, D. U. (2015). Keefektifan Cooperative Learning Tipe Jigsaw dan STAD Ditinjau dari Prestasi Belajar dan Kepercayaan Diri Siswa. Pythagoras: Jurnal Pendidikan Matematika, 10(1), 1-14. https://doi.org/10.21831/pg.v10i1.9091.

Hossain, A., \& Tarmizi, R. A. (2013). Effects of Cooperative Learning on Students' Achievement and Attitudes in Secondary Mathematics. Procedia - Social and Behavioral Sciences, 93, 473-477. https://doi.org/10.1016/j.sbspro.2013.09.222.

Johnston, A. Y. \& M. (2017). The impact of school-based assessment for qualifications on teachers' conceptions of assessment. 638-654. https://doi.org/• https://doi.org/10.1080/0969594X.2017.1295020.

Kartowagiran, B., \& Jaedun, A. (2016). Model Asesmen Autentik Untuk Menilai Hasil Belajar 
Siswa Sekolah Menengah Pertama (Smp): Implementasi Asesmen Autentik Di Smp. Jurnal Penelitian Dan Evaluasi Pendidikan, 20(2), 131. https://doi.org/10.21831/pep.v20i2.10063.

Khadijah, K., Arlina, A., Hardianti, R. W., \& Maisarah, M. (2021). Model Pembelajaran Bank Street dan Sentra, serta Pengaruhnya terhadap Sosial Emosional Anak. Jurnal Obsesi: Jurnal Pendidikan Anak Usia Dini, 5(2). https://doi.org/10.31004/obsesi.v5i2.1054.

Kolhar, M., Kazi, R. N. A., \& Alameen, A. (2021). Effect of social media use on learning, social interactions, and sleep duration among university students. Saudi Journal of Biological Sciences, 28(4), 2216-2222. https://doi.org/10.1016/J.SJBS.2021.01.010.

Leniati, B., \& Indarini, E. (2021). Meta Analisis Komparasi Keefektifan Model Pembelajaran Kooperatif Tipe Jigsaw Dan Tsts ( Two Stay Two Stray ) Terhadap Kemampuan Berpikir Kritis Pada Pembelajaran Matematika Siswa Sekolah Dasar. Mimbar IImu, 26(1), 149-157. https://doi.org/10.23887/mi.v26i1.33359.

Lynch, M., Sage, T., Hitchcock, L. I., \& Sage, M. (2021). A heutagogical approach for the assessment of Internet Communication Technology (ICT) assignments in higher education. International Journal of Educational Technology in Higher Education, 18(1). https://doi.org/10.1186/s41239-021-00290-x.

Majid, M. S. Z. B. A., Ali, M. M. B. A., Rahim, A. A. B. A., \& Khamis, N. Y. B. (2012). The Development of Technical English Multimedia Interactive Module to Enhance Student Centered Learning (SCL). Procedia - Social and Behavioral Sciences, 67, 345-348. https://doi.org/10.1016/j.sbspro.2012.11.337.

Marhamah, M., \& Mulyadi, M. (2013). Jigsaw Cooperative Learning: A Viable TeachingLearning Strategy? Journal of Educational and Social Research, 3(7), 710-715. https://doi.org/10.5901/jesr.2013.v3n7p710.

Mulyana, M. A., Hanifah, N., \& Jayadinata, A. K. (2016). Penerapan Model Kooperatif Tipe Numbered Heads Together (NHT) untuk Meningkatkan Hasil Belajar Siswa pada Materi Kenampakan Alam dan Sosial Budaya. Jurnal Pena IImiah, 1(1), 331-340. https://doi.org/10.23819/pi.v1i1.3039.

Musyarofah, M. (2018). Pengembangan Aspek Sosial Anak Usia Dini Di Taman KanakKanak Aba Iv Mangli Jember Tahun 2016. INJECT (Interdisciplinary Journal of Communication), 2(1), 99. https://doi.org/10.18326/inject.v2i1.99-122.

Nashirotun, B. (2020). Peningkatan Aktivitas dan Hasil Belajar Siswa dengan Metode Jigsaw dan Media Tubuh Manusia pada Pembelajaran IPA di MTs. Negeri 4 Klaten Jawa Tengah. Jurnal Paedagogy, 7(4), 402. https://doi.org/10.33394/jp.v7i4.2945.

Nugraha, Purnamasari, I., \& Tanuatmodjo, H. (2016). Interaction Between the Type of School and Learning Outcomes in Student's Soft Skills Enhancement through Cooperative Learning Model (Quasi Experiment on Vocational Students in Bandung). Procedia - Social and Behavioral Sciences, 219. https://doi.org/10.1016/j.sbspro.2016.05.078.

Nurfitriyanti, M. (2017). Pengaruh Model Pembelajaran Kooperatif Tipe Jigsaw Terhadap Hasil Belajar Matematika ditinjau dari Kecerdasan Emosional. Formatif: Jurnal IImiah Pendidikan MIPA, 7(2). https://doi.org/10.30998/formatif.v7i2.2229.

Nurhusain, M. (2017). Impact Analysis of Cooperative Learning Model Application Type Two Stay Two Stray (Tsts) Toward Learning Outcomes of Mathematics. JPMI (Jurnal Pendidikan Matematika Indonesia), 2(2), 46. https://doi.org/10.26737/jpmi.v2i2.220.

Nurmahmidah. (2017). Penerapan Model Pembelajaran Kooperatif Tipe Teams Games Tournament (Tgt) Pada Pokok Bahasan Peluang Sebagai Upaya Meningkatkan Prestasi Dan Motivasi Belajar Matematika Siswa Kelas X Mia 2 Sma Negeri 1 Sedayu. Jurnal Mercumatika, 1(2), 65-72. https://doi.org/10.26486/mercumatika.v1i2.252.

Nurmiyati, \& Suyata. (2014). Keefektifan Paired Storytelling Dan Jigsaw Dalam Peningkatan Kompetensi Berbicara Siswa Kelas VIII SMP Negeri 3 Sleman. Jurnal Ling Tera, 1(2), 210-223. https://doi.org/10.21831/lt.v1i2.2597. 
Ozan, C. (2019). The effect of authentic assessment on academic achievement and attitude towards educational measurement and opinions of prospective teachers. International Journal of Evaluation and Research in Education, 8(2), 299-312. https://doi.org/10.11591/ijere.v8i2.18564.

Pantiwati, Y. (2016). Hakekat Asesmen Autentik Dan Penerapannya Dalam Pembelajaran Biologi. Jurnal Edukasi Matematika Dan Sains, 1(1), 18. https://doi.org/10.25273/jems.v1i1.773.

Putra, I. B. P. A., Pujani, N. M., \& Juniartina, P. P. (2018). Pengaruh Model Pembelajaran Kooperatif Tipe Jigsaw Terhadap Pemahaman Konsep Ipa Siswa. Jurnal Pendidikan Dan Pembelajaran Sains Indonesia (JPPSI), 1(2), 80. https://doi.org/10.23887/jppsi.v1i2.17215.

Qusyairi, L. A. H., \& Sakila, J. (2018). Pengaruh Model Cooperative Learning Tipe InsideOutside Circle (IOC) terhadap Prestasi Belajar dengan Memperhatikan Minat Belajar Matematika. Palapa: Jurnal Studi Keislaman Dan IImu Pendidikan, 6(1), 34-49. https://doi.org/10.36088/palapa.v6i1.57.

Saguni, F. (2013). Efektivitas Metode Problem Based Learning, Cooperative Learning Tipe Jigsaw, Dan Ceramah Sebagai Problem Solving Dalam Matakuliah Perencanaan Pembelajaran. Cakrawala Pendidikan, 1(2). https://doi.org/10.21831/cp.v0i2.1478.

Sari, C. R., Hartati, S., \& Yetti, E. (2019). Peningkatan Perilaku Sosial Anak melalui Permainan Tradisional Sumatera Barat. Jurnal Obsesi : Jurnal Pendidikan Anak Usia Dini, 3(2). https://doi.org/10.31004/obsesi.v3i2.225.

Sari, M. K. (2014). Pengaruh Metode Kooperatif Jigsaw Terhadap Prestasi Belajar Mata Pelajaran IPS Pada Siswa Kelas III. Jurnal Pendidikan Dasar Dan Pembelajaran, 4(2), 113-144. https://doi.org/10.25273/pe.v4i02.313.

Sean Kelly, Andrew M. Olney, P. (2013). T Automatically Measuring Question Authenticity in Real-World Classrooms Show. JPI (Jurnal Pendidikan Indonesia), 2(2), 138-144. https://doi.org/10.23887/jpi-undiksha.v2i1.1410.

Sinclair, E. E. J. \& J. (2017). Ontario's educational assessment policy and practice: a doubleedged sword? 655-677. https://doi.org/10.1080/0969594X.2017.1329705.

Soedimardjono, F. P., \& Pratiwi, P. (2021). Cooperative Learning Model with Jigsaw Type Improves Students ' Sciences Process Skills and Learning Outcomes. 10(1), 172179. https://doi.org/10.23887/jpi-undiksha.v10i1.25203.

Souvignier, E., \& Kronenberger, J. (2007). Cooperative learning in third graders' jigsaw groups for mathematics and science with and without questioning training. British Journal of Educational Psychology, 77(4), 755-771. https://doi.org/10.1348/000709906X173297.

Subiyantari, A. R., Muslim, S., \& Rahmadyanti, E. (2019). Effectiveness of Jigsaw Cooperative Learning Models In Lessons of the Basics of Building Construction on Students Learning 'Outcomes Viewed From Critical Thinking Skills. International Journal for Educational and Vocational Studies, 1(7), 691-696. https://doi.org/10.29103/ijevs.v1i7.1653.

Supriyadi, E., Zamtinah, Soenarto, S., \& Hatmojo, Y. I. (2019). A character-based assessment model for vocational high schools. Cakrawala Pendidikan, 38(2), 269280. https://doi.org/10.21831/cp.v38i2.24099.

Susanto, H. (2012). Faktor-faktor yang mempengaruhi kinerja guru sekolah menengah kejuruan. Jurnal Pendidikan Vokasi, 2(2). https://doi.org/https://doi.org/10.21831/jpv.v2i2.1028.

Tatminingsih, S. (2019). Kemampuan Sosial Emosional Anak Usia Dini di Nusa Tenggara Barat. Jurnal Obsesi: Jurnal Pendidikan Anak Usia Dini, 3(2), 484. https://doi.org/10.31004/obsesi.v3i2.170.

Usmanova, N., Shindina, T., \& Basharina, A. (2015). Development and Assessment of Interactive Teaching Approach Impact on Communicative Competence of Bachelors of Economic Universities. Procedia - Social and Behavioral Sciences, 214. https://doi.org/10.1016/j.sbspro.2015.11.701. 
Wardani, D. T. (2015). Pengaruh Pembelajaran Kooperatif Tipe Stad (Student Teams Achievement Divisions) Dan Jigsaw Terhadap Prestasi Belajar Ekonomi Ditinjau Dari Motivasi Belajar Siswa Tahun Ajaran 2014/2015. EQUILIBRIUM: Jurnal IImiah Ekonomi Dan Pembelajarannya, 3(2), 105-112. https://doi.org/10.25273/equilibrium.v3i2.657.

Wardani, \& Wiyasa, I. K. N. (2020). Pengaruh Model Pembelajaran Kooperatif Tipe Jigsaw Berbasis Catur Paramitha Terhadap Kompetensi Pengetahuan Matematika. Jurnal Pedagogi Dan Pembelajaran, 3(1), 25-33. https://doi.org/10.23887/jp2.v3i1.24358.

Widyaningrum, M. D., \& Harjono, N. (2019). Pengaruh Model Pembelajaran Jigsaw Terhadap Hasil Belajar Ips Siswa Kelas 4 Sekolah Dasar. JPPGuseda / Jurnal Pendidikan \& Pengajaran Guru Sekolah Dasar, 2(2), 57-60. https://doi.org/10.33751/jppguseda.v2i2.1446.

Wiliam, P. B. \& D. (n.d.). Classroom assessment and pedagogy. Pages 551-575. https://doi.org/10.1080/0969594X.2018.1441807.

Wulandari, R., Ichsan, B., \& Romadhon, Y. A. (2017). Perbedaan Perkembangan Sosial Anak Usia 3-6 Tahun Dengan Pendidikan Usia Dini Dan Tanpa Pendidikan Usia Dini Di Kecamatan Peterongan Jombang. Biomedika, 8(1), 47-53. https://doi.org/10.23917/biomedika.v8i1.2900.

Yemi, T. M., Binti, N., \& Azid, H. (2018). Effect Of Jigsaw Strategy Of Cooperative Learning On Mathematics Achievement Among Secondary School Students. European Journal of Education Studies, 51-61. https://doi.org/10.5281/zenodo.1167888.

Yuan, C.-H., \& Wu, Y. J. (2020). Mobile instant messaging or face-to-face? Group interactions in cooperative simulations. Computers in Human Behavior, 113. https://doi.org/10.1016/j.chb.2020.106508.

Zakiah, R. R., \& Samlawi, F. (2019). Improve the Responsibility of Student By Cooperative Learning Model Type Jigsaw At Social Studies Class. International Journal Pedagogy of Social Studies, 4(2), 7-14. https://doi.org/10.17509/ijposs.v4i2.19516. 